\title{
Undoing the "Cemetery of the Living": Performing Change, Embodying Resistance through Prison Theater in Nicaragua
}

Reverter o "cemitério dos vivos": concretizar a mudança, corporizar a resistência através do teatro de prisão na Nicarágua

Inverser le "cimetière des vivants": concrétiser le changement, donner corps à la résistance grâce au théâtre de prison au Nicaragua

Julienne Weegels

\section{OpenEdition}

\section{Journals}

Electronic version

URL: http://journals.openedition.org/rccs/9770

DOI: $10.4000 /$ rccs. 9770

ISSN: 2182-7435

Publisher

Centro de Estudos Sociais da Universidade de Coimbra

Printed version

Date of publication: 1 December 2019

Number of pages: 137-160

ISSN: 0254-1106

Electronic reference

Julienne Weegels, « Undoing the "Cemetery of the Living": Performing Change, Embodying Resistance through Prison Theater in Nicaragua », Revista Crítica de Ciências Sociais [Online], 120 | 2019, Online since 12 December 2019, connection on 14 December 2019. URL : http://journals.openedition.org/ rccs/9770; DOl : 10.4000/rccs. 9770

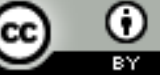




\section{JULIENNE WEEGELS}

\section{Undoing the "Cemetery of the Living": Performing Change, Embodying Resistance through Prison Theater in Nicaragua}

This paper explores the gendered and spatialized dynamics that underpin prisoners' and official discourses of "change" (cambio de actitud) in Nicaragua as these were manifested at two prison facilities during a lengthy period of prison theater training. Teasing out the way in which "change" is resisted, adapted and appropriated by prisoners as they simultaneously embody and contest state discourses of penal reeducation, I argue that while re-educational spaces present opportunities for "doing freedom", temporarily relieving the tightness of prison, they are also fundamentally part of the prison's power structure and political-moral realm. Herein change is often posited as opposed to violence, yet my research points to a dialectical relationship rather than a binary opposition between the two, because within the wider co-governance system of Nicaragua's prisons, violence appears to exist in a parallel rather than past relationship to prisoners' processes of change.

Keywords: criminal justice; Nicaragua; penal system; prison; social reintegration; theater.

\section{Introduction}

Nicaraguan prisons are administered through a progressive privilege system that is guided by a penal ideology of reeducation (reeducación penal) that is set in its Penitentiary Law. ${ }^{1}$ According to that Law, participation in penal reeducation is crucial to achieving prisoner "change of attitude" (cambio de actitud), a process that is rewarded with (significant) sentence reduction. As a result, the penitentiaries attempt, at least officially, to organize as much of prison life as possible around re-educational programs. The challenge for imprisoned (young) men and women then lies in confronting their criminalization by convincingly "changing". Prisoner performances of

${ }^{1}$ Ley No. 473 (2003), Ley del Régimen Penitenciario y Ejecución de la Pena, La Gaceta, Diario Oficial No. 222, 21 de noviembre de 2003. Asamblea Nacional de la República de Nicaragua. 
change do, however, also confront authority conceptions of change, which tend to conflate cambio de actitud not only with desistance from crime, but also with a positive attitude toward (poor) living conditions. This envisioned positive attitude includes a purportedly 'pro-communitarian' moral orientation, along the lines of Nicaragua's particular citizen security model, for the implementation of which the country's community policing strategy and re-educational penal system are the main pillars. ${ }^{2}$

In this essay, I explore the effects of prison as a moral institution through the dialogical relationship between its institutional performance and the political-moral realms in which it is embedded. The latter are articulated through the institutional emphasis on citizen security, which (re)produces particular social and prison-related stigma and as such can be understood as producing particular gendered and classed subjects of intervention (Levenson, 2013; Weegels, 2018a, 2018b). In this way, particular "noncitizen" subjects are identified for exclusion from the community and deemed fit for imprisonment. Even if the Penitentiary Law holds that prisoners deserve a second chance or, at the very least, that in spite of their prior actions they should be treated humanely, ${ }^{3}$ the Law is but a small part of a hybrid and much wider system of governance. Within the Nicaraguan prison world, this system of governing powers operates through what prisoners colloquially refer to as el Sistema (the System). It concretely encompasses the different parts of the criminal justice system (police, judiciary and prison system) and, at a more abstract level, the relational system of state and non-state political actors that are able to exert power over and through the state apparatus, including its executive, legislative and governing institutions. According to prisoners, it is by the rules of this Sistema "that this country works" (Marlon City Police Jail, 2016). ${ }^{4}$

Through the Sistema, police and prison authorities systematically take discretionary decisions and deploy extralegal force against prisoners to establish who is in charge (quién manda). It is also by way of the Sistema

\footnotetext{
${ }^{2}$ For a close consideration of the way in which the Nicaraguan government (2007 to present) uses the criminal justice system as a vital arena for implementing social policies directed at "wayward" youths, see Weegels (2018b). It must be noted that from April 2018 onwards the violent repression of anti-government protests (leaving over 300 dead and 800 imprisoned, most of them young), has definitively altered the public perception of policing and imprisonment in Nicaragua, as well as the government's discourse around community policing and imprisonment, bringing its long well-hidden repressive and politicized face into the public eye (for a discussion of this topic see Weegels, 2018c).

3 The adjective "humanitarian" (bumanitario) has been incorporated into the institutional slogan of the Nicaraguan National Penitentiary System.

${ }^{4}$ All prisoners' names throughout the article are pseudonyms and all prisoners' quotes have been translated by me.
} 
that prison authorities collude with groups of powerful prisoners to run prison life with its extralegal markets. In this way, the Sistema represents at once the (legal) criminal justice system and an extralegal system of state power melded with political and criminal power, where entanglements of (para)state and (para)criminal governance are manifest in different configurations of state and non-state power on the ground. Akin to the "criminal governance networks" described by Arias (2006), the Sistema produces co-governance arrangements between prisoner hierarchies and authorities that are indicative of a "hybrid state" (Jaffe, 2013).

Most importantly, this Sistema and the political-moral realm of reeducación penal (formally organized under the Direction of Penal Reeducation, from here on referred to as Reeducación Penal) give Nicaraguan prisons a peculiar "tightness" (Crewe, 2011) that impinges itself on prisoners both morally and materially. Reeducación Penal has been a key part of Nicaragua's prison system since its genesis under the revolutionary-socialist Sandinista regime in the 1980s (Centeno Mayorga, 2012), when education was considered a fundamental element for the production of New Men and Women (Guevara, 1985 [1972]; Montoya, 2012). Even though the administrations of the so-called neoliberal period (1990-2006) sought to eradicate the (remnants of the) Sandinista state upon its electoral defeat in 1990, they only succeeded to a limited extent. Members of the Sandinista party continued to hold significant positions in (among others) state institutions concerned with national security, such as the police, army, and prison system. Aside from this, the party proceeded to "govern from below" by regularly paralyzing the country through general strikes and protests, organized through an extensive para-state system of trade unions, cooperatives, and student and youth movements directly affiliated with the party (e.g. Rocha Gómez, 2007). When president Ortega - the leader of the Sandinista party since 1984 - was re-elected in 2006 (and subsequently in 2011 and 2016), the rearrangement of the state under the political-moral slogan "socialism, Christianity, and solidarity" soon came into effect and began significantly re-politicizing state institutions, including those falling under the criminal justice system. This means that prisoners and their required cambio de actitud are inevitably embedded in the Sandinista state's political-moral economy.

This paper suggests that by performing change and appropriating re-educational spaces, prisoners make claims to morality and social value in the face of systemic violence. In these spaces, they resist for instance the notion that they are inherently immoral. Such moral claims tend to surface especially when prisoners consciously reflect on their desire to 
change, on the process of change itself, on achieving or failing to achieve it, as well as moments when they attest to the moral contradictions of the authorities and the Sistema. After presenting in the next section the key concepts trough which I engage with prisioner change, I explore in three empirical sections first the mortifying effects of the "cemetery of the living" (as prisoners refer to prison) and the chances of reverting the prisoners' experience of social death in re-educational spaces. Then, I consider how prisoners appropriate re-educational spaces to counter stigmatization and present themselves as "good men". Finally, I explore the way in which the authorities misrecognize prisoners' performances of change. Throughout I consider the way in which apparently opposing prisoner performances of violence and change co-exist not as opposite ends of a behavioral binary, but rather as constantly co-present parallel aspects of the prison experience, exacerbated by the Sistema. This parallel engagement with violence and change is key if we wish to understand how prisoners move through prison, both across time and space.

\section{Prison Space and Doing Change}

Arguably, the "tightness" of Nicaragua's prison system is almost entirely defined by its ambiguous moral character (Crewe, 2011). The prison's physical space - its carceral geography - is architecturally divided into spaces for encounters with the outside (re-educational and visitor spaces) and spaces cut off from the outside (cell blocks and dormitories). While these spaces tend to overlap in function, they differ in carceral quality in so far as some areas have a distinctly more carceral "feel" than others. Recently, a number of prison sociologists, criminologists, and (carceral) geographers sought to spatialize prison's "carceral grip" by mapping out the ways in which power relations and governance systems become pervasive in prisons and the ways in which the "pains of imprisonment" (Sykes, 2007 [1958]) fluctuate spatially and take on different qualities (see for example Allspach, 2010; Crewe, 2011; Crewe et al., 2014; Hancock and Jewkes, 2011; Moran, 2014, 2016). Some prison spaces can then be seen as inherently more, or less, "prison-like", depending on how their Foucauldian disciplinary power strengthens or dissipates (Foucault, 1991). In the light of this, and building on King and McDermott's (1995) distinction between the "depth" and "weight" of imprisonment, criminologist Ben Crewe (2011) has brought forward the notion of prison's tightness.

Where the depth of imprisonment "suggests being buried far from liberty, deep below the surface of freedom", and weight denotes "the degree to which it [prison] weighed them [prisoners] down or bore upon them", Crewe proposes the notion of tightness to give "a sense of the way that 
power is experienced as both firm and soft, oppressive and yet also somehow light. It does not so much weigh down on prisoners and suppress them as wrap them up, smother them and incite them to conduct themselves in particular ways" (Crewe , 2011: 521-522). More specifically, tightness relates to re-educational spaces and practices, because what elicits a response of the control system in such practices is not so much the legal violations as "the possibility of being sanctioned for breaching institutionally defined norms" (ibidem: 522). This blurs the boundaries between "criminal" and sanctionable behavior, leaving boundary definition to the discretion of individual prison administrations. The arena of penal reeducation thus becomes the space par excellence to perform both "obedience" and resistance to the progressive privilege system.

By putting forward their own understandings of moral authority, justice and change, prisoners seek to contest their social stigma and call into question the supposed moral superiority of the authorities. In my observation, one of the ways in which they did this was by appropriating re-educational spaces for "doing freedom". Thomas Ugelvik conceptualizes "doing freedom" as the way in which prisoners both take liberties and resist power in prison through boundary-crossing actions. ${ }^{5} \mathrm{He}$ explains that

If power and freedom are inherent variables, it is precisely by confronting various forms of power that people can "do" freedom in practice. In these circumstances, the authorities' boundary that is crossed represents an absolutely necessary part of the free action. It is performative because boundary-crossing actions affect the actor. The prisoners take liberties, $d o$ resistance and become free. (Ugelvik, 2014: 6; my emphasis)

Yet even as prisoners exert their claims to social worthiness or resist the prison space and its power system by "doing freedom", such performances remain part and parcel of being confined. It has been argued, for instance, that while arts or educational activities inside prison may well provide avenues for resistance or transcendence, they are also avenues through which power and authority are reiterated in distinct, "softer" ways that are geared to the reproduction of (prison) order. ${ }^{6}$ Re-educational spaces, then, rather than providing relief from the prison environment, reflect an intrinsic part of the tightness of the Sistema

\footnotetext{
${ }^{5}$ I purposely use Ugelvik's performative understanding of freedom and resistance, which engages to a certain extent with James Scott's classic approach to resistance $(1985,1990)$ but simultaneously steps away from the premise that "doing" freedom equals resisting domination, just as I believe that "doing" change - even though it can be made to actively resist stigmatization - does not necessarily equal challenging penal domination.

${ }^{6}$ See for example Cheliotis (2014) for a consideration of prison arts in this light, and O'Neill (2015) for a consideration of religious intervention in prison centers as "soft security".
} 
- particularly through the arbitrary allocation of privileges and issuance of early release orders, in a circular agreement between the Nicaraguan National Penitentiary System (DGSPN, in the Spanish acronym) and the Ministry of Governance.

\section{Prison Theater in the "Cemetery of the Living"}

Between 2009 and 2016 I conducted 31 months of ethnographic field research with convicted prisoners and former convicts (whom I refer to as former prisoners) from two different prison facilities. Trained as an anthropologist and initially interested in the gendered dynamics of violence and change of attitude in prisons, I accessed the prison world by way of a prison theater initiative that my husband - Mick, a Nicaraguan theater director - and I set up. Between 2009 and 2013, we worked with a group of men serving long sentences in a Regional Penitentiary System (SPR, according to the Spanish acronym for Sistema Penitenciario Regional). ${ }^{7}$ Between 2015 and the beginning of 2016, we worked with a group prisoners with shorter sentences from a City Police Jail $(\mathrm{CPJ})$ at a police-run community center. ${ }^{8}$ With both groups, I conducted many hours of participant observation and engaged in numerous informal and group conversations. I also followed up with many of my research participants outside of prison and set-up a former-prisoner radio show with a number of them. Throughout my research, the theater-in-prison programs provided my spatial and temporal entry points into the prisoner world. ${ }^{9}$ These spaces, where Mick

\footnotetext{
7 This group consisted of between eight and twenty members, all of whom were young men (mostly between 18 and 30 years old at the time), who had been sentenced to between 6 and 30 years in prison (which is Nicaragua's legal maximum sentence).

${ }_{8}$ This group consisted of 13 to 15 members, all but two of them young men (also between 18 and 30 years old at the time, though on average younger than the group at the SPR), who had been sentenced to between 2 and 5 years in prison.

${ }^{9}$ We were both volunteers and never received any pay from the DGSPN or National Police. While the content of the program itself was never subject to any kind of open vetting by the authorities - an officer would often be present during the first couple of workshops, probably due to a mixture of curiosity, security concerns, and some need to make sure we were not doing anything they believed we should not -, all we had to do was let prisoners join the program, occasionally drop into the penal reeducation director's office (or the police captain's, in the case of the CPJ), and appear at the facility at agreed-upon times. On a political level, however, as facilitators, Mick and I were subjected to vetting. Over the course of time, as the hold of the government on state institutions tightened, we were increasingly asked for proof of sympathy for and/or affiliation with the Sandinista party, its policies and ideology. We were also expected not to breach the code of public secrecy surrounding the prison system, on penalty of losing access and being ostracized (as has been the case with most human rights organizations, deprived of any access since 2008, and has also been the fate of most press, non-religious and non-government aligned initiatives - including, in the end, our own). It was over time, then, that my research - originally approved by the local warden - became a partially undisclosed endeavor, of which only the participating prisoners were fully aware. I have dedicated much reflection to the practical and ethical dilemmas (and potential ramifications) of conducting ethnographic research in such conditions.
} 
and I were more often than not unaccompanied by the authorities, provided valuable emergent contexts for understanding the prisoner-participants' views, experiences, and performances of violence and change, both with and against the Sistema.

In their vernacular, the prisoners with long sentences at the SPR talked of prison as a "cemetery of the living". Manuel, an older prisoner sentenced to life in prison, used this phrase frequently. Loco, who was serving a 15-year bid, noted that he felt "buried alive" in the prison. After his release, Javi, who served eight and a half years of an 18-year bid, noted that prison was "where I was dead". This death, as these prisoners call it, is of a social kind. Existence, to them, is social realization - that is to say, personal fulfillment within society, on the outside. As Douglas explained, "we're like the dead because we don't exist outside". Just as a cemetery holds its dead, prison holds the socially-dead, confined to a space at once neglected, abandoned, and denied by the "outside". As a result, "decay" in prison took on various forms. It is manifest in the neglect of personal hygiene, psychological torment, poverty and the loss of family support, and also in the increasing decay of the surrounding environment: the smoke-blackened kitchen and its nauseatingly musky odor of stale tortillas and rice gone bad, the faded paint, grungy floors, rusty beds, broken toilets, leaking roofs, overcrowded cells, and heavy prison air. While the state is omnipresent in the shape of its agents and the building itself, it also makes itself felt as deliberately negligent and selectively absent.

This cemetery is thoroughly social, however. Its social nature dates back to the prison system's genesis - under a revolutionary-socialist government, in the $1980 \mathrm{~s},{ }^{10}$ which determined its physical set-up - and has been exacerbated by overcrowding (Darke and Garces, 2017; Weegels, 2017). While social death entails the demise of the prisoner's outside social life (one's reputation, the withering and death of friendships, family relations, love, and once-held expectations of social worth), it also imposes a different kind of sociality: a forced sociality of continuous physical co-presence with men faced with the same fate. A sociality that takes the prisoner's body to extremes it may never have experienced as a man on the outside: sleeping on a damp floor, underneath someone else's bed or next to the toilet-shower, smelling of that floor, getting a fungus or developing a rash, living on less than a square meter, in constant physical negotiation with others occupying the same space. "I feel like my body no longer belongs to me [mi cuerpo ya no me pertenece]", Araña (CPJ, 2015) said. Thus, the prisoner's body

${ }^{10}$ For an idea of the Soviet-style "carceral collectivism" by which the then-new Nicaraguan prison system was partially inspired, see Piacentini and Slade (2015). 
becomes "a social object, a locus of contested control, and a target to be edited and narrated by others" (Henry, 2006:380). Viewed in this light, bodies are not simply subject to restraining environments, they "articulate" with them as sites "where identity and meaning can be actively reconfigured into socially and personally acceptable ways for understanding" (ibidem: 391). By asserting that prison is a "cemetery of the living", prisoners evoke not just a socially mortified self (in the sense of Goffman's mortification, 1991), but also a social presence on the margins of society and a physical presence in a place where nobody wants to be. Implicit in this is the imposed context that consists of the deprivation of exterior sociality and its replacement with forced participation in the prison's interior sociality - a participation that must be carefully considered in terms of both release and survival, and one from which nobody walks away unscathed.

\section{Kafkaesque Metamorphoses}

In early 2010, we read Franz Kafka's Metamorphosis with the prison theater group at the SPR. ${ }^{11}$ The predicament of Kafka's Gregory Samsa resonated with the prisoners in ways we could not have imagined. Samsa wakes up one day transformed into an insect, without knowing exactly why. While planning a trip, he finds himself unable to leave his bed, and there he discovers his new form. With gruesome hairy legs sticking out from his sides, and covered in a brown shell, he realizes that he may have become something like a cockroach. When he begins to explore the margin for maneuver which his new form leaves him, he quickly finds out that he feels restrained not only by his own form, but also by the way people now see him. Initially ashamed, later misunderstood, Gregory is confined to his room, where he is poked at, ridiculed, abused, and from which he appears unable to escape. As we reflected on the story together, the prisoners noted that:

I see myself in Gregory, you know, waking up one day made into an insect, spat out by society.

The way his father mistreats him, throwing that apple that rots into him...

And it's his sister who tries to help him, but she can't, in the end, change him, you know. She's kind of afraid of him too, I guess.

\footnotetext{
${ }^{11}$ We gave every member of the group a photocopy of the book, so that they could read passages out loud during the workshops, make notes, and keep it for re-reading. For this we used the open access Spanish translation of the book, available, for example, at Biblioteca Virtual Universal (https://www.biblioteca.org.ar/libros/1587.pdf, last accessed on 29.07.2019).
} 
He's so trapped.

He has to find a way to live as an insect though, before it crushes him.

We spent a month discussing the Metamorphosis before it began to morph into a prison theater play. Breaking through the text and into staged interaction, the theater facilitator, Mick, approached the collective creative process in a particular way - a way that much influenced what I observed in the prison environment, the kinds of topics I could discuss with the prisoners, and the level of trust (confianza) that emerged. Most importantly, his theater methodology drew on an understanding of the prisoners' bodies as "idioms through which expressions of deeply personal and social trauma become manifest" (Henry, 2006:391). That is, as sensitive objects with their own memories, standing in relation to their physical experience, narration, and other bodies. In order to approach the prisoners and their personal histories in this way, Mick drew on a shared history of violence and socio-psychological memories of pain and trauma (referred to as duelos) that tied him to the prisoners as people, which minimized "the difference between me and you [to] you being in here". The created theater space thus broke pre-established boundaries, both physical and social. Harm, hurt, addiction, darkness, and stuckness all became discussable, if not verbally then at least through the physical idiom of theater.

While theater is often thought of as wearing masks and learning the lines to an imaginary part on a fictional stage, this approach to theater instead reached beyond the actor's mask by drawing on his body. ${ }^{12}$ "I will not ask you why you're here or what you did, I don't care what you did or did not do", Mick stressed, "we'll be working based on our physical histories, the things our bodies have experienced, we will let those speak" (my emphasis). By confronting physical experience, the prison-as-space became fundamental to the theater-making process, and, interestingly, in this confrontation the carceral grip appeared to loosen. At the SPR, Ben, a prisoner

\footnotetext{
${ }^{12}$ Mick's approach to theater is both "posthuman" and physical, and loosely braids together three theorists of the actor and the stage. Its approach to acting (as a political act), motivation, and justification is akin to Bertold Brecht's political theater and Tadeusz Kantor's theater of the dead, and its use of unconventional spaces relates to Jersy Grotowksi's theater laboratory. Usually, Mick takes a particular text (such as Kafka's Metamorphosis) as the basis for constructing a play, in which the (prisoner-)actors' own stories and physical histories become the leading elements. Aesthetically, his approach is strongly inspired by Peter Brooke's "empty space", while also drawing on the iconoclasm, textures and ruptures proposed by scenographer-directors Jan Fabre and Romeo Castellucci. In its search for an unmistakable physical idiom of violence and oppression - seeking to go beyond the spoken word -, it finds inspiration in butob dance and performance theater.
} 
sentenced to life in prison who was in his early thirties at the time, became the appointed leader of the group. Often, the group would already be waiting to start practice, and tell us off if we were late or if practice was cancelled. Seven of the participants never missed a practice in four years (except when they had a visit or court date). On the other hand, there were regular "off days" when none of the participants felt like doing anything. These were a recurrent part of the prison routine, when they were "just tired of being locked up (encerrado)", Junior explained. In this way, as theater training became embedded in the prison routine, so the theater space became a space where prisoners could "do freedom". By (re-)appropriating their bodies in the prison context, the prisoner-actors resisted the restrictions and boundaries imposed on them.

This (temporary) re-appropriation of their bodies for themselves eased the grip of a system that controlled their movements and disciplined their bodies into cohabitation in overcrowded cells where rules governed how one's body should be treated and how one was to treat other people's bodies. Even if it may appear that the rules of Reeducación Penal are being followed to perfection - after all, they are participating in a re-educational activity and even if we see participation in re-educational activities as working, from the authorities' point of view, toward a cambio de actitud, then this very aspect of it, i.e., the possibility of appropriating re-educational spaces under the authorities' nose, made the free actions in which the prisoner-actors engaged through their participation in penal reeducation very inconspicuous yet also very flagrantly boundary-crossing, these crossings being ultimately aimed at subverting the space afforded to them by the authorities (Ugelvik, 2014). Re-educational spaces, then, can provide for performances quite different and significantly more subversive than "changing attitudes".

\section{Respectable "Thieves", Self-Aware "Subjects"}

As noted above, the prisoners' understandings of change often differed from and reached beyond the institutional framework. Thus, sometimes their performances were tense negotiations over what changing means. The authorities' requirement of change entailed a noticeable and visible adjustment of one's attitude - both in the sense of mentality and behavior toward a more socially and morally acceptable script that implied desisting from crime and criminal - i.e., "immoral" - behavior. Even if prisoners indeed viewed change as a reconsideration (or evolution) of one's outlook on life (in terms of mentality), they disagreed about the extent to which such change should be made noticeable and visible to the authorities in terms of adjusted behavior, and on whether (non-violent) crime was in 
fact immoral. Instead, the prisoners' grasp of change oftentimes had to do with moral notions about what it means to be a "good man". While this reflected their sense of being "bad" men (either as prisoners and/or at some previous point in their lives), it also implied their rejection of the notion that it is the authorities who hold the power to define what being a "good" man is. At this point, it is important to understand that the gendered norms of machismo - here understood as a gendered system of power relations that (re)produces inequalities between men and women, but also among men and women (Lancaster, 1992) - still shape the basic tenets of interaction between and among prisoners and the authorities as men (see also Weegels, 2014). As such, the honor of the prisoners as men both antedates and supersedes the prison context. In fact, one of the most important things while in prison is to remain a respectable man - keeping one's word, commanding and showing respect - as opposed to snitching, lying or betraying others to get one's way (ibidem). Being a "good man" in prison, then, hinged more on abiding by these principles and on spiritual as well as peer- or family-oriented understandings of change than on the discourses promoted by authorities that many prisoners perceived as empty, having seen firsthand how (some of) those authorities engaged in such disrespectful and dishonorable behavior as the beating up of prisoners (a predictably unequal fight), deceit and corruption. Importantly, while, in the eyes of the prisoners, be(com)ing a good man often entailed be(com)ing more respectful toward spiritual moral authorities or their families, it did not necessarily include desisting from money-making crime, especially if the latter meant providing for their families from inside the prison.

Thus, being perceived as "good" while in prison seemed to depend on the type of space one found oneself in, and therefore encompassed performing different understandings of change. More specifically, re-educational spaces seemed to provide a place where not only the "cemetery of the living" could be re-signified and as such (temporarily) undone - or suspended -, but also where the preconceptions associated with the stigma of prison could be proven wrong. Such actions have a preferred audience, and contrary to what one may think, it is not primarily the prison staff, but rather those outside. By becoming more than just prisoners, by claiming life and humanity, the prisoners made particular moral assertions that unsettle the social stigmas surrounding prison and its inhabitants. I will illustrate this with three short examples in which prisoners establish themselves as decent/ /good men within the re-educational space and explore the alternative, gendered moral frameworks to which these performances relate. First, as I wrote down in my field notes, 
When we got home after only the second class we had ever taught at the SPR, in mid-2009, Mick realized that he had forgotten his sweatshirt inside. He had taken it off while engaging in physical exercises with the group. According to the ley de la gallada, and similarly to the rule of the street, "si te dormiste, te fuiste" that is, "if you fall asleep, you're gone", i.e. if you don't pay attention, you're robbed. Accordingly, Mick had no expectation whatsoever of seeing his sweatshirt back again, if not on someone else's body. The next class, however, Ben walked up to Mick first thing with his sweatshirt clean and neatly folded in his hands. "You forgot this", he said. Very surprised, Mick thanked him, considering this small act a great demonstration of respect. (SPR, 2009)

In effect, through this small act the prisoner-participants had taken the opportunity to present themselves as non-delinquents and to define prison as other than the street, thus giving the lie to the stigma they know is attributed to their circumstances. Were they stereotypical "delinquents"? Maybe, but they presented themselves as respectful workshop participants who could be trusted with other people's belongings.

This counted for my own status as a "belonging" "la mujer de Mick", Mick's woman/wife) too, and similarly held for family visits. Nobody's mother, sister, wife or daughter was to be harassed by another prisoner. Following this logic, were any participant to intimidate or hurt a female visitor, they would become the object of the wrath of their male counterparts, who would feel compelled to defend their honor by degrading their assailant's. One might believe that, as stigmatized subjects, they have no honor left, but that is false. The prisoners' honor as men both antedates and supersedes the prison context. In fact, as has been said, one of the most important things in prison is to remain a respectable man. In this sense, the gendered norms of machismo combined with the prisoners' desire to counter the stigma of prison, promoted an environment in which no harm would come to a woman. ${ }^{13}$

If respect for outsider relations and "property" is the first cardinal value of prison life, ${ }^{14}$ the second concerns not so much the outsider-visitor but the maintaining of (access to) the spaces in which the latter can be received. Since prison is experienced as a cemetery, when the authorities vacate a space in which outsiders are received, prisoners conquer a degree of freedom that resembles life. To them, interaction with outsiders, especially if

${ }^{13}$ This is not to say that it does not happen, but when it does happen it is considered a grave breach of the prisoners' own "rules of conduct", and could lead to prisoner-administered punishment.

${ }^{14}$ This also explains why prisoners are so upset when authorities attempt to meddle in their personal relations - an issue that prisoners regularly complained about. 
unmediated by the authorities, most closely resembles life on the outside. One way to make the authorities feel that they can routinely vacate these spaces is by assuring them that nothing defined as violent or "criminal" happens in their absence. Consequently, in re-educational spaces (as well as visiting areas) prisoners are compelled to police each other. After all, the misbehavior of one can end up in punishment for all. This "policing" extends beyond each other's behavior, to protecting outsiders that take the time to be with them and their property. In fact, this self-policing is part and parcel of the co-governance system. What this also means, in short, is that particular types of surveillance, security provision, and maintenance of order are carried out either by prisoners or shared between prisoners and the authorities.

A key aspect of this self-policing is the defusing of conflict in re-educational spaces, which leads to my third and final illustration. In the middle of a rehearsal for a prison theater play in the SPR class hall, Cheetah -23 years old at the time - grabbed Ben's butt. Not only did this fly in the face of an age- and sentence-based hierarchy of respect, it was also understood as an attempt to feminize Ben or to attract his (sexual) attention. Ben left the class hall immediately. At the start of the next practice, he noted that he had "wanted to punch the living daylights out of him [Cheetah]". The restraint he imposed on himself not to do so, stemmed from his respect for the space we were in. The fact that he returned to the subject, however, made it clear that he felt that as a man he had to assert that he should have punched the living daylights out of Cheetah - and he wanted to leave no doubt as to his manhood. The fact that Ben's leaving the class (rather than resorting to violence) occurred within the re-educational space, however, was not called into question by the other prisoner-participants. Similarly, when participants in the CPJ prison theater group had issues with fellow participants they never resorted to physical violence to resolve them within the re-educational space.

It is important to understand that this reaction is significantly different from, but also parallel to, what is expected within a prison cell. At the SPR, Zopi, who was in his early thirties at the time and already with 11 years of his 20-year sentence behind him, was suspended from theater training for three months because he had participated in a cellblock brawl. In the same brawl, theater participant Mono stabbed another prisoner and was suspended for the year. While Reeducación Penal does not reconcile the parallel engagements of prisoners in violence, re-educational spaces and the values attached to them by prisoners do mediate the violence (both physical and structural) that characterizes prison life outside these spaces. 
In this sense, one may conceive of re-educational spaces, with regard to their weight, depth and tightness, as not so much heavy and deep, but nonetheless tight in their carceral grip, given that they mobilize the prisoners' constant policing of one another so as not to lose the spaces that they come to value for their capacity to temporarily undo the "cemetery".

\section{Recognition?}

The daily effort that the participants in re-educational programs put into behaving in preparation for a life beyond prison, beyond the "cemetery", made it understandable that they stressed their own agency in achieving this "change". Though the police captain at the community center stressed the fact that "change always comes from either love or fear", if anything, change did not appear to come by way of words spoken by someone in a police uniform. Even if the CPJ prisoners were grateful for the opportunity to swap their prison cell for the community center, being "rehabilitated" in a space provided by the same police that had arrested them did not sit comfortably with all of them. The prisoners were highly aware of what their captors thought of them. Even the Juvenile Affairs unit police captain noted that many police officers "think this way: shoot them all or lock them up and throw away the key". He added: "that's why it's always a struggle to convince the jefatura [local police authority] of the validity of this program, but it motivates me to make the program work; by giving these kids some positive attention, they may change and inspire others to stop doing harm to society". But the apparent discrepancy between the captain's - and his colleagues' - way of thinking and the captain's alleged involvement in corruption meant that to the prisoners his words were "just words", "sheer blah-blah [pura palabrería]".

Distrust between CPJ prisoners and the police was such that many participants were convinced that "this whole thing, you know, treating us nicely, is a fucking lie". Marlon said "they think they can block the sun with a finger [tapar el sol con un dedo]", trying to make one good thing outshine all the bad - "the bad" being the extralegal side of the Sistema. ${ }^{15}$ The bulk of the prisoners I worked with had been beaten up by the police, and in order to "get off the hook" or mitigate the weight of the charges or of the length of a sentence, most of them were forced to pay significant sums of money to the police, the prosecutor's office, or the judiciary. Still, in spite of the Sistema, or perhaps due to it, there is promise in Reeducación Penal, a legal

${ }_{15}$ For an extensive exploration of how prisoners view policing, imprisonment, and politics, see Weegels (2019). 
underpinning that makes it worthwhile to engage in it, despite the risk of misrecognition: this is the two-for-one (dos por uno) principle. In a nutshell, this rule holds that every day spent in re-educational activities (education, culture, sports, work or worship) counts for two days of the sentence. In this way, by actively engaging in reeducation, prisoners can reduce their sentences by as much as half. Most prison theater group members thus kept up their performances of change assiduously, venting their discontent with the arbitrariness and slow pace of the Sistema only occasionally and in confidence (en confianza). Fully focused on the promise of early release, they engaged in the (mental) balancing act required to navigate both the cell spaces and re-educational spaces in ways that would reflect positively on their records.

At the community center, for instance, CPJ-prisoner Araña willingly and repeatedly stepped into the police spotlight to advertise how much he had changed. Eager to be released, he would accompany the Juvenile Affairs unit to give prevention talks (charlas) at high schools. With this he made his change visible to the authorities, but also exposed himself to being perceived exactly as a prisoner by the youths he addressed. Clearly, the police were glad to make use of Araña's readiness to display his changes, but Araña had his own expectations too. After two other group members were released on a collective pardon, partially brought about by a prison riot, Araña got his hopes up. Halfway into his sentence he spent six weeks on end, right up to Christmas 2015, "buying into" the promise that he would be released "next week". When his mother came to visit in the week before Christmas, after she had gone to the courts before they closed for the holiday, she told him (visibly upset) that the judge was not even aware that he was participating in the rehabilitation program. It hit Araña like a ton of bricks that his attempt to become visible to the authorities had failed, in the sense that it had not caught the eye of the one authority who was in a position to decide his fate: the judge. I sat across from him and his mother at the table at which we had just shared lunch, as he lay down on the bench, swallowing down the reality of spending another Christmas behind bars. It dawned on him that all the time he had spent making himself visible to the police counted for nothing in the way of helping him toward an early release. A short hour later, he had pulled himself together:

I've done everything possible, Juliana. I've participated as one of the best students in almost all of the courses here. [...] I really thought they [the police] would at least acknowledge what I've done, but what can I say? That's the way it is, whatever [ni modo]. I'm not going to let it get me down. (Araña, CPJ, 2015) 
The Juvenile Affairs captain should have pushed captain Soza, in charge of reporting prisoner behavior at the CPJ, to send a good behavior report to the judge prior to Araña's mid-sentence court date. After all, he was the one who directly benefited from Araña's willingness to participate in the prevention talks. As theater facilitators we vouched for Araña's excellent contribution to the theater-training program, but in the absence of essential police documentation, the letter of recommendation we wrote had little effect on the judge. In Araña's mind, he was doing two-for-one, but so long as the judge in charge of implementing the sentence reduction was kept in the dark, and so long as his participation was not reflected on his prisoner record, his performances of change went legally unrecognized.

But why would Araña trust the authorities to do their administrative duty in the first place? He was surely aware of how the Sistema worked, and cognizant of its backdoor negotiations. After all, he was also a leader of his cell, meaning that parallel to his engagement in penal reeducation, he was engaged in asserting prison order - a role that usually involves violence and some participation in the prison's internal illicit economy. One explanation is that, despite being able to manage both aspects (spatial and temporal) of his movements in prison in detail, Araña was "short-timing". Other prison researchers have pointed out how prisoners focus increasingly on their future in preparation for reentry into the community as their release dates approach (e.g. Burnett and Maruna, 2004; Irwin, 1987 [1970]; Seim, 2016). In these studies, prisoners who are "short" of being released (referred to as "short-timers") are often viewed as "daydreamers" with unrealistic expectations of their successful reentry, which inevitably leads to disappointment with post-prison reality. Prison ethnographer Josh Seim (2016: 444), however, argues that these authors fail to understand short-timers' future-oriented perceptions and practices of reentry as "prison-centric", making them much more a part of prison than of the reentry process. If we understand "short-timing" as a prison-centered activity, he argues, it can tell us much more about "tactical conduct behind bars" (rather than about actual reentry aspirations) and thus enable an understanding of "penal domination as a likely source of short-timer hope" (ibidem: 443, my emphasis). Seim describes how (in his United States context) short-timers "often volunteer in life skills programs, collect recommendation letters from prison labor supervisors, and network with family and friends outside prison for employment and shelter" (ibidem). It is exactly these activities that prisoners participating in re-educational programs continuously engage in.

What is different about Seim's United States context is that release dates in Nicaragua are never fixed, and that an early release can be aspired to 
at just about any point during the sentence. Short-timing then becomes a coping strategy in the face of what is frequently perceived as an undefined period of imprisonment. Aspiring to a prompt release, but also set on going through prison "on top" rather than suffering at the bottom of the prisoner hierarchy, Araña had engaged in re-educational activities hoping that these would work toward that release, while also making sure that his life inside his cell was one of power rather than powerlessness. Even though he regularly adjusted his expectations for actual release, these (painful) adjustments occurred repeatedly around "special" dates, at which times prisoner pardons and early release orders are often issued (for instance around Christmas and Easter). Arguably, short-timing makes prisoner participation in penal reeducation appear very transcendental and instrumental (the future is both within reach and at stake), but also very disappointing, because it holds out the prospect of a reward that is engrained in the structures of penal domination. Most prisoners are quite aware of this effect, however. Referring to Araña, Marlon (CPJ, 2015) noted:

I don't know why he [Araña] keeps getting his hopes up. He should know better, he knows what he's in for and there's no way they're letting him off easy. This way he's only helping them, thinking that he's also helping himself. But it doesn't work like that, the Sistema only benefits the Sistema. You know I'm over half of my five years, but I don't expect to be released. If it's five years it's five years, ni modo. I'm here [in the re-educational program] because it's better being here than locked up 24/7 seeing the same faces and hearing the same stories. [I'm here] because I get to see my family, because some of the stuff I learn here can be useful. Sure, I'd like to get out early, but I don't expect anything from the cops and I don't want to owe them anything. They're only looking after their own interests here, so I look after mine.

Marlon saw his participation in reeducation as an option for his present time, and did not necessarily attach any implications or aspirations for his future to it. Of course, he had post-release plans, but he did not discuss them nearly as much as Araña did. For young prisoners like Araña, short-timing was a way of channeling hope (and resources) toward a (possibly near) future as they attempted to make the best of their time while also trying to get out from underneath its weight. For others, like Marlon, who nonetheless participated in re-educational activities (that is, in the theater group), short-timing appeared futile, immature. Years after being released from the SPR, Beto noted there was a difference between prisoners who "accept their sentence" and those who "only think of getting out". In reference to his best friend Samuel, who was sentenced to life at the SPR, he said: 
Samuel's strong. He's sitting out his time like a man. Not a lot of guys can do that. He said to himself "if it's 25 years it's 25 years", and accepted his time. He's not going crazy counting the hours, you know, but sitting tight, tranquilo. (Beto, former SPR, 2015)

In this way, short-timing can be seen in relation to the prison sentence and the resources one is able to mobilize toward an early release (connections, family, money, faith, and prison-based resources such as the "points" from penal reeducation on the prisoner record). With these resources in place, it is perhaps not necessary to "accept" the sentence or "face" prison time ("like a man" or otherwise). While Araña's frustration came from his sudden confrontation with the weight of prison time, which was a hard blow indeed, he rapidly recovered and re-focused on the resources he could deploy in a second, or twentieth, round against hard time.

\section{Conclusion}

Through a close consideration of re-educational spaces in prison, especially with regard to the prison theater program, I have attempted to demonstrate the way in which prisoner understandings of change differ from penal reeducation's push to "change attitudes". I have explored the ways in which performances of change differ not only according to audience, but also according to the stage, and how these stages are contested and appropriated both by prisoners and the authorities. I have also sought to relate prisoner performances of change to the prison's wider political-moral realm and system of governance, which is not only made up of institutional moralities and public discourses, but also permeated by local moral understandings and gendered norms (both institutionalized and otherwise) that reach beyond prison.

If we understand performance as "doing", and performing change as a means to freedom, then the state-imposed moral framework can be appropriated to counter public discourse/stigma and resonate with redemption scripts (Maruna, 2001). While a cambio de actitud needs to be made visible to the authorities in order to be registered, "changing" can also be used to resist - to resist the institutional framework, to resist one's stigmatization, and to become free both literally and symbolically. Literally in the sense that their participation in such activities might actually (if temporarily) remove them from the prison confines, by allowing them to participate in a community center program or even to obtain an early release order. Symbolically in the sense that prisoners take liberties by engaging in re-educational activities.

The main question is: if we take into account the context of structural and physical violence governing much of prison life in Nicaragua, then the 
prescribed change of attitude and its promise of early release can easily become a form of "cruel optimism" imposed on the prisoner (Berlant, 2011; O'Neill and Fogarty-Valenzuela, 2015). Are we justified in pushing a prisoner to think not only beyond the prison's walls but also of an outside world and a future that is significantly more welcoming than the reality in which he lived before going to prison? On the other hand, if the prisoner does not transcend those walls from time to time, albeit through illicit phone calls to his loved ones, the occasional or daily toke of a marihuana joint, or participation in re-educational activities, does he not run the risk of sliding deeper and deeper into the "cemetery"? Prisoners have a term for that, quemar cable - burning cables, the cables being the neurons wasted on worrying over one's incarcerated condition. And such states of "over-worrying" bring with them their own risks to the prison order, which is balanced precisely on the prisoners' willingness to keep their heads. Being respected as a "changed man" on a long-term prison sentence can significantly ease relations with prison authorities and expedite family and conjugal visits, making life on the inside less lonely. However, these coveted rewards, especially any type of (temporal) release, are not guaranteed, nor distributed equally, nor are they equally appreciated by all prisoners.

Change, then, is mapped onto the prison's space and scheduled into its time in particular ways. Is it transcendental? Is it transformative? Or might we better understand it as made up of temporary, performative transpositions - balancing acts that allow for a consideration of the parallel nature of prison, the parallel nature of change itself? In his ethnography of Christian piety and "soft" security in the context of the Guatemalan gang crisis, anthropologist Kevin O’Neill (2015) briefly mentions the notion of parallel-ness when he describes the involvement of an imprisoned gang leader ("Gustavo") in the murder of four police officers during a prison riot. Gustavo was also, however, in the process of converting to Christianity. And after Gustavo was murdered, O'Neill finds himself in the company of the pastor who had been working with him, standing in the prison where Gustavo had been held. In his description of the interaction with the pastor, he notes how "Pastor Morales tried to reason through Gustavo's compartmentalizing his emerging Christianity from these killings. It was a different (meaning parallel, rather than past) part of his life. The distinction proved too tedious to explain" (ibidem: 42). But isn't it a key distinction? "Change" and "violence", reeducation and co-governance, co-exist inside the prison. For Araña, Marlon, Ben, Beto, Junior, Javi, and all the others, violence existed in parallel with, rather than prior to, their process of changing. 
Although penal reeducation contributes to much of the prison system's "tightness" - making activities as wide-ranging as primary education, religion, and theater complicit with the carceral environment - the ways in which prisoners navigate this tight environment makes them agents rather than subjects or objects of disciplinary power. They are capable of altering or subverting the experience of that environment, and it is both with and against these moral institutions and society's gendered imaginaries that prisoners engage in such navigation. When this is taken together with the prisoners' own moral claims to being "good" men, building on their own conceptions of "change", prison as a moral institution becomes social, plural, and shared - something that does not "belong" to the authorities alone, but to the prisoners as well. It is important to point out that, in their eyes, it is other people - those who engage with them on different emotional, educational, creative or spiritual exploits outside the correctional premises - and they themselves who make reeducation a truly moral enterprise. Rather than perceiving themselves as subjects subordinated to the disciplinary or moralist power/knowledge regime, they proclaim themselves and their "collaborators" as the agents of their own moral change. While this agentic appropriation of penal reeducation unhinges Foucauldian notions of a "total education" or omnipresent disciplinary power, these claims are still made from a position that is thoroughly subordinated to the powerful moral-political regimes in place - regimes that hold the power to decide whether their change is "good" enough or "genuine" enough, that is, changed enough. It is with this inherent contradiction in prison's moral work in mind that prisoners continuously struggle, even after their release, to demonstrate their worthiness to society.

Edited by João Paulo Moreira

\section{References}

Allspach, Anke (2010), "Landscapes of (Neo-)Liberal Control: The Transcarceral Spaces of Federally Sentenced Women in Canada”, Gender, Place \& Culture, 17(6), 705-723.

Arias, Enrique Desmond (2006), “The Dynamics of Criminal Governance: Networks and Social Order in Rio de Janeiro”, Journal of Latin American Studies, 38(2), 293-325.

Berlant, Lauren (2011), Cruel Optimism. Durham: Duke University Press.

Burnett, Ros; Maruna, Shadd (2004), "So 'Prison Works', Does It? The Criminal Careers of 130 Men Released from Prison under Home Secretary, Michael Howard”, The Howard Journal of Criminal Justice, 43(4), 390-404. 
Centeno Mayorga, Darvyn (2012), Manual de Derecho Penitenciario Nicaragüense. Managua: SENICSA Editorial.

Cheliotis, Leonidas (2014), "Decorative Justice: Deconstructing the Relationship between the Arts and Imprisonment", International Journal for Crime, Justice and Social Democracy, 3(1), 16-34.

Crewe, Ben (2011), "Depth, Weight, Tightness: Revisiting the Pains of Imprisonment”, Punishment \& Society, 13(5), 509-529.

Crewe, Ben; Warr, Jason; Bennett, Peter; Smith, Alan (2014), “The Emotional Geography of Prison Life", Theoretical Criminology, 18(1), 56-74.

Darke, Sacha; Garces, Chris (2017), "Surviving in the New Mass Carceral Zone”, Prison Service Journal, 229, 2-9.

Foucault, Michel (1991), Discipline and Punish: The Birth of the Prison. London: Penguin Books. Translated by Alan Sheridan [orig. 1975].

Goffman, Erving (1991), Asylums: Essays on the Social Situation of Mental Patients and Other Inmates. London: Penguin Books [orig. 1961].

Guevara, Ernesto (1985), La Guerra de Guerrillas. La Habana: Editorial de Ciencias Sociales [orig. 1972].

Hancock, Philip; Jewkes, Yvonne (2011), “Architectures of Incarceration: The Spatial Pains of Imprisonment”, Punishment \& Society, 13(5), 611-629.

Henry, Doug (2006), "Violence and the Body: Somatic Expressions of Trauma and Vulnerability During War”, Medical Anthropology Quarterly, 20(3), 379-398.

Irwin, John (1987), The Felon. Berkeley: University of California Press [orig. 1970].

Jaffe, Rivke (2013), “The Hybrid State: Crime and Citizenship in Urban Jamaica”, American Ethnologist, 40(4), 734-748.

King, Roy; McDermott, Kathleen (1995), The State of Our Prisons. Oxford: Clarendon Press.

Lancaster, Roger (1992), Life is Hard: Machismo, Danger, and the Intimacy of Power in Nicaragua. Berkeley, CA: University of California Press.

Levenson, Deborah (2013), Adiós Niño: The Gangs of Guatemala and the Politics of Death. Durham: Duke University Press.

Maruna, Shadd (2001), Making Good: How Ex-Convicts Reform and Rebuild Their Lives. Washington, D.C.: American Psychological Association.

Montoya, Rosario (2012), Gendered Scenarios of Revolution: New Men and New Women in Nicaragua, 1975-2000. Tucson: University of Arizona Press.

Moran, Dominique (2014), "Leaving behind the 'Total Institution'? Teeth, Transcarceral Spaces and (Re)Inscription of the Formerly Incarcerated Body", Gender, Place \& Culture, 21(1), 35-51.

Moran, Dominique (2016), Carceral Geography: Spaces and Practices of Incarceration. London: Routledge.

O'Neill, Kevin Lewis (2015), Secure the Soul: Christian Piety and Gang Prevention in Guatemala. Berkeley: University of California Press. 
O’Neill, Kevin Lewis; Fogarty-Valenzuela, Benjamin (2015), “On the Importance of Having a Positive Attitude", in Javier Auyero; Philippe Bourgois; Nancy Scheper-Hughes (eds.), Violence at the Urban Margins. Oxford: Oxford University Press, 73-91.

Piacentini, Laura; Slade, Gavin (2015), “Architecture and Attachment: Carceral Collectivism and the Problem of Prison Reform in Russia and Georgia”, Theoretical Criminology, 19(2), 179-197.

Rocha Gómez, José Luis (2007), "Mapping the Labyrinth from Within: The Political Economy of Nicaraguan Youth Policy Concerning Violence", Bulletin of Latin American Research, 26(4), 533-549.

Scott, James C. (1985), Weapons of the Weak: Everyday Forms of Peasant Resistance. New Haven: Yale University Press.

Scott, James C. (1990), Domination and the Arts of Resistance: Hidden Transcripts. New Haven: Yale University Press.

Seim, Josh (2016), "Short-Timing: The Carceral Experience of Soon-to-Be-Released Prisoners", Punishment \& Society, 18(4), 442-458.

Sykes, Gresham (2007), The Society of Captives: A Study of a Maximum Security Prison. New Jersey: Princeton University Press [orig. 1958].

Ugelvik, Tomas (2014), Power and Resistance in Prison: Doing Time, Doing Freedom. London: Palgrave Macmillan.

Weegels, Julienne (2014), “The Prisoner's Body: Violence, Desire and Masculinities in a Nicaraguan Prison Theatre Group”, in Georg Frerks; Johanna Louisa Ypeij; Reinhilde Sotiria König (eds.), Gender and Conflict: Embodiments, Discourses and Symbolic Practices. Farham: Ashgate, 151-173.

Weegels, Julienne (2017), "Prisoner Self-Governance and Survival in a Nicaraguan City Police Jail”, Prison Service Journal, 229, 15-18.

Weegels, Julienne (2018a), “The Terror and Scourge of the Barrio': Representations of Youth Crime and Policing on Nicaraguan Television News", Journal of Latin American Studies, 50(4), 861-887.

Weegels, Julienne (2018b), "Implementing Social Policy through the Criminal Justice System: Youth, Prisons, and Community-Oriented Policing in Nicaragua”, Oxford Development Studies, 46(1), 57-70.

Weegels, Julienne (2018c), "Inside Out: Confinement, Revolt, and Repression in Nicaragua", PoLAR: Political and Legal Anthropology Review - Speaking Justice to Power Series, October 3. Accessed on 03.04.2019, at https://politicalandlegalanthro. org/2018/10/03/inside-out-confinement-revolt-and-repression-in-nicaragua/.

Weegels, Julienne (2019), "El sistema, la policía y la política vistos desde adentro: Un acercamiento al Estado carcelario nicaragüense de cara a la represión”, Estudios Centroamericanos, 74(756), 147-172. 
Received on 01.05.2019

Accepted for publication on 03.07.2019

\author{
Julienne Weegels \\ Centre for Latin American Research and Documentation (CEDLA), Faculty of Humanities, \\ Universiteit van Amsterdam \\ Roetersstraat 33, $5^{\text {th }}$ floor, 1018WB Amsterdam, The Netherlands \\ Contact: j.h.j.weegels@cedla.nl \\ ORCID: https://orcid.org/0000-0001-7988-9903
}

\section{Reverter o "cemitério dos vivos": concretizar a mudança, corporizar a resistência através do teatro de prisão na Nicarágua}

Este artigo explora a dinâmica de género e de espaço, que sustenta tanto o discurso oficial como o dos reclusos sobre "mudança" (cambio de actitud) na Nicarágua, tal como se manifestou em dois estabelecimentos prisionais durante um longo período de formação de teatro na prisão. Identificando a forma como os reclusos resistem, adaptam e se apropriam da "mudança", ao mesmo tempo que corporizam e contestam os discursos oficiais da reeducação penal, argumento que, muito embora os espaços de reeducação apresentem oportunidades para "fazer liberdade", aliviando temporariamente a tensão da prisão, eles também fazem parte fundamental da estrutura de poder e do domínio político-moral da prisão. Aqui, a mudança costuma ser posta em oposição à violência, mas a minha pesquisa aponta mais para uma relação dialética do que para uma oposição binária entre as duas, uma vez que dentro do sistema de cogovernação mais amplo das prisões da Nicarágua, a violência parece existir numa

\section{Inverser le "cimetière des vivants": concrétiser le changement, donner corps à la résistance grâce au théâtre de prison au Nicaragua}

Cet article se penche sur la dynamique de genre et d'espace, qui nourrit tant le discours officiel que celui les détenus sur le "changement" (cambio de actitud) au Nicaragua, tel que cela s'est manifesté dans deux prisons durant une longue période de formation de théâtre en prison. Nous avons mis en relief la façon dont les détenus résistent, s'adaptent et finissent par s'approprier du "changement", tout en corporisant et en contestant les discours officiels de rééducation pénale, et l'on soutient que, bien que les espaces de rééducation offrent des chances de "créer la liberté”, en soulageant temporairement la tension de la prison, ils font aussi fondamentalement partie de la structure du pouvoir et du domaine politico-moral de la prison. Ici, le changement est normalement opposé à la violence, mais nos recherches soulignent davantage un rapport dialectique qu'une opposition binaire entre les deux, puisque dans le système de co-gouvernance plus ample des prisons du Nicaragua, 
160| Julienne Weegels

relação paralela, mais do que passada, aos processos de mudança dos reclusos.

Palavras-chave: justiça criminal; Nicarágua; prisão; reintegração social; sistema penal; teatro. la violence semble exister dans une relation parallèle, plus que passée, des procédures de changement des détenus.

Mots-clés: justice pénale; Nicaragua; prison; réinsertion sociale; système pénal; théâtre. 